\title{
HISTORICAL VARIATIONS OF LEMON CREEK GLACIER, ALASKA, AND THEIR RELATIONSHIP TO THE CLIMATIC RECORD
}

\author{
By Calvin J. Heusser \\ (American Geographical Society, New York, U.S.A.) \\ and Melvin G. Marcus \\ (Department of Geography, Rutgers University, New Brunswick, New Jersey, U.S.A.)
}

\begin{abstract}
Lemon Creek Glacier served as the focus of attention of the Juneau Ice Field Research Project from 1953 through 1958, during which period glaciological and related research was accomplished. This paper provides an historical framework for those studies by ( $\mathrm{I}$ ) considering variations of Lemon Creek Glacier in recent centuries and during millennia since the last ice age, and (2) describing certain relationships which appear to exist between these variations and the climatic record.

It is found that Lemon Creek Glacier has been receding intermittently since a maximum $c$. $175^{\circ}$ and by 1958 had lost $c .25$ per cent of the former area. Most rapid recession occurred during the periods $189 \mathrm{I}-1902$ and $1929-58$. Behaviour of the glacier since $c$. 1750 reveals a parallelism with glaciers in most of the regions where temperature trends have been graphed as well as with other glaciers of the Juneau Ice Field. The advances of the 1950's observed in the Rocky, Cascade and Olympic Mountains do not, however, show up in the Juneau area. Lemon Creek Glacier has not advanced more than $375 \mathrm{~m}$. beyond the $175^{\circ}$ position,
if at all, during the last Io,0oo yr.
\end{abstract}

Résumé. Le Lemon Creek Glacier a été le centre d'intérêt du Juneau Ice Field Research Project de 1953 à 1958 , période au cours de laquelle ont été réalisées des recherches glaciologiques. Cet article fournit un cadre historique pour ces études: $\mathrm{I}^{\circ}$ ) en considérant les variations du Lemon Creek Glacier dans les siècles récents et durant des millénaires depuis la dernière glaciation; $2^{\circ}$ ) en décrivant certaines relations qui semblent exister entre ces variations et les enregistrements climatiques.

Nous avons trouvé que le Lemon Creek Glacier est en récession intermittente à partir d'un maximum situé aux environs de $175^{\circ}$ et qu'en $195^{8}$ il a perdu à peu pres $25 \%$ de son aire initiale. Une récession plus rapide s'est produite durant les périodes $189 \mathrm{I}-1902$ et $1929-58$. Le comportement du glacier depuis 1750 révèle un parallélisme avec ceux des régions où les tendances tempérées ont été notées aussi bien qu'avec les autres glaciers du Juneau Ice Field. Les avances aux environs de 1950, observées dans les Rocky, Cascade et Olympic Mountains, ne sont cependant pas visibles dans la région du Juneau. Le Lemon Creek Glacier n'a pas avancé de plus de $375 \mathrm{~m}$ au-delà de sa position de 1750 , durant les derniers 10 ooo ans.

Zusammenfassung. Der Lemon Creek Glacier stand im Mittelpunkt des Interesses des Forschungsunternehmens am Juneau Ice Field von 1953-58; während dieser Periode wurden glaziologische und verwandte Untersuchungen durchgeführt. Die vorliegende Abhandlung vermittelt einen historischen Rahmen für diese Untersuchungen durch ( I) Analyse der Schwankungen des Lemon Creek Glaciers in den letzten Jahrhunderten und während der Jahrtausende seit der letzten Eiszeit und (2) Beschreibung gewisser Beziehungen, die zwischen diesen Schwankungen und dem Klimaablauf zu bestehen scheinen.

Es zeigt sich, dass sich der Lemon Creek Glacier seit einem Hochstand um 1750 mit kurzen Unterbrechungen im Rückzug befindet und r 958 etwa $25 \%$ seiner früheren Ausdehnung verloren hat. In den Perioden 1891-1902 und 1929-58 verlief der Rückzug besonders schnell. Das Verhalten des Gletschers seit I $75^{\circ}$ zeigt einen Parallelismus zu den Gletschern der meisten Gebiete, in denen Temperaturverhältnisse aufgezeichnet worden sind, und ebenso zu anderen Gletschern des Juneau Ice Fields. Die Vorstösse, die während der 5oer-Jahre in den Rocky, Cascade und Olympic Mountains zu beobachten waren, sind jedoch im Juneau-Gebiet nicht aufgetreten. Der Lemon Creek Glacier ist während der letzten Io ooo Jahre-wenn überhaupt-nicht mehr als $375 \mathrm{~m}$ über den Stand von $175^{\circ}$ vorgestossen.

\section{INTRODUCTION}

Lemon Creek Glacier, a small valley glacier located in the Coast Mountains of southeastern Alaska, has been the subject of glaciological and related studies since the summer of I953. The results of this research and the literature relating to it have been summarized by the authors in a presentation of mass balance and flow data for the period $1953^{-5} 8$ (Heusser and Marcus, I964). It is the purpose of this paper to provide an historical framework for these recent investigations by ( $\mathrm{I}$ ) considering variations of Lemon Creek Glacier in recent centuries and during millennia since the last ice age, and (2) describing certain relationships which appear to exist between these variations and the climatic record. 


\section{The Glacier during Recent Centuries}

The hydrological budgets of the glacier, which showed a net deficit of $10.32 \times 10^{6} \mathrm{~m} .{ }^{3}$ during the years of the Project's observations, have presumably covered a wide range of variations in the past. When the glacier advanced to a down-valley maximum, c. $2 \cdot 5 \mathrm{~km}$. below that of $195^{8}$, a long series of surplus budget years must have prevailed in order to bring about this change. When the glacier later receded, on the other hand, negative budgets are presumed to have been rife except when the terminus at times readvanced and recessional moraines were formed. A chronological base is essential for correlating these variations with those of other glaciers and with the climatic fluctuations causing them. For this reason, positions of the terminus were recorded and dated between the down-valley maximum and I $95^{8 .}$.

Dating was accomplished following the dendrochronological methods outlined by Lawrence (1950[a]). A Swedish increment corer was used to take cores at the bases of Sitka spruces (Picea sitchensis) through to their growth axes, and the age of each tree was found by counting the number of rings in a complete basal core. When the number of years that elapsed between the time the glacier receded from a site and the time the cored tree began to grow was added to this age, a date for the deglaciation of the site could be obtained. The interval amounts to $c$. Io yr. and was derived by subtracting the age of the oldest spruce studied in I954 ( 5 yr.) which was growing on a surface known from an aerial photograph to have been occupied by the glacier in 1929 , from the time since the photograph was taken (25 yr.). Although the actual intervals were probably longer or shorter at different localities because of conditions prevailing from place to place, the ro yr. figure was added to the ages of all trees dated on the moraines and outwash.

The sharp trimlines and crescentic terminal and recessional moraines of the classic glaciated valley are not distinct in the area below Lemon Creek Glacier. Trimlines occur in places and moraines are found, but because of the relative narrowness and steepness of the valley, avalanching from the valley sides has probably erased or disturbed most of the formerly more extensive or readily recognizable features. Sufficient evidence, nevertheless, is at hand to indicate the area into which the glacier advanced. The down-valley recent ice limit is marked by a trimline which runs down along a ridge that stands transverse to the valley. This ridge appears to have acted as a barrier to the advancing ice.

The vegetation down-valley from the ice maximum is composed of ancient stands of hemlocks and spruce. Many of the trees are rotten at the core and are several centuries in age. The heavy litter, formed in part by rotting stumps and fallen trunks, further substantiates that the forest is ancient. The most cogent piece of evidence pertaining to the age of the surface, however, is from a muskeg located $c .375 \mathrm{~m}$. down-valley from the trimline. A sample of basal peat from a depth of $5.8 \mathrm{~m}$. was radiocarbon dated through the courtesy of Professor J. L. Kulp at Lamont Geological Observatory. Its age of $10,300 \pm 600 \mathrm{yr}$. (Olson and Broecker, 1959) indicates that Lemon Creek Glacier has not advanced as much as $375 \mathrm{~m}$. beyond its recent ice maximum, if at all, for roughly ı,00o yr.

The vegetation up-valley from this maximum becomes progressively younger as the snout of the glacier is approached. The oldest trees on the lower outwash are Sitka spruces close to two centuries in age. Trees are clearly first generation and have grown up in the open. They have broad bases and conical form compared to the ancient forest trees which exhibit narrowbased columnar growth. Mountain hemlocks (Tsuga mertensiana) also grow on the outwash but are few in number and are widely scattered. Most prevalent are alder (Alnus) and willow (Salix), particularly on the more recently deglaciated surfaces. Stands of black cottonwood (Populus trichocarpa) cover large portions of the slopes. These represent a successive stage beyond alder and willow and will eventually be replaced by Sitka spruce which is becoming conspicuous in the understories. The many alpine plants established on the outwash disclose the fact that the area is a tension zone, probably created by cold air drainage from the glacier. 


\section{LEMON CREEK GLACIER SYSTEM}

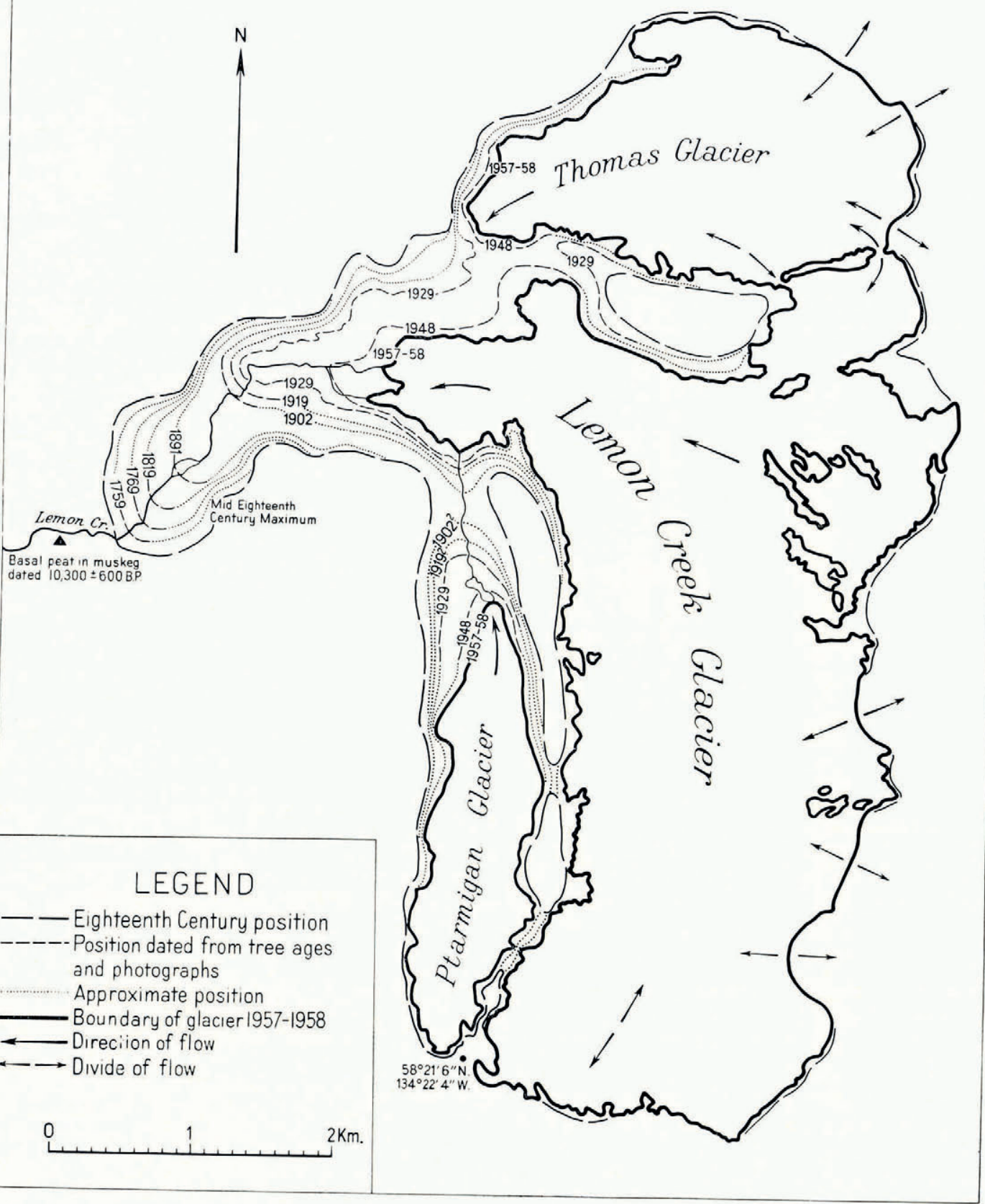

Fig. I. Map of the Lemon Creek Glacier system showing positions of the glacier margin between the mid-eighteenth century and
19.57-58 
The dated positions of the glacier as it receded from the down-valley maximum are shown in Figure I. The measured changes in the Lemon Creek Glacier system, which represents the junction of Lemon Creek, "Thomas" and "Ptarmigan" Glaciers, are given in Table I and Figure 2. These data show two episodes of relatively slow wastage, each followed by rapid diminution. Between the mid-eighteenth and late-nineteenth centuries (c. I 40 yr.), only $0.82 \mathrm{~km} .{ }^{2}$ of the glacier wasted, and the terminal retreat was $675 \mathrm{~m}$. In the short span between $\mathrm{I} 89 \mathrm{I}$ and $\mathrm{I} 902$, by contrast, loss was pronounced and amounted to an area of

Table I. Changes in the Lemon Creek Glacier System between the

\section{Dated position terminus}

Maximum, c. $175^{\circ}$

Maximum, I 759

$1759-69$

I $769-1819$

1819-9I

1891-1902

1902-19

1919-29

I929-48

$194^{8-5}{ }^{8}$ Mid-eighteenth Century and $195^{8}$

\begin{tabular}{|c|c|c|c|c|c|c|c|}
\hline \multirow{2}{*}{$\begin{array}{c}\text { Glacier area } \\
\mathrm{km}^{2}\end{array}$} & \multicolumn{2}{|c|}{ Area loss } & \multicolumn{2}{|c|}{$\begin{array}{c}\text { Cumulative } \\
\text { area loss }\end{array}$} & \multirow{2}{*}{$\begin{array}{c}\text { Terminal } \\
\text { recession } \\
\mathrm{m} .\end{array}$} & \multirow{2}{*}{$\begin{array}{c}\text { Cumulative } \\
\text { terminal } \\
\text { recession } \\
\mathrm{m} .\end{array}$} & \multirow{2}{*}{$\begin{array}{c}\text { Recession } \\
\text { rate } \\
\mathrm{m} . / \mathrm{yr} \text {. }\end{array}$} \\
\hline & $\mathrm{km} .^{2}$ & per cent & $\mathrm{km} .^{2}$ & per cent & & & \\
\hline $24 \cdot 64^{x}$ & - & - & - & - & - & 一 & - \\
\hline $24 \cdot 45^{\mathrm{I}}$ & $0 \cdot 19$ & 0.8 & $0 \cdot 19$ & 0.8 & 100 & 100 & 一 \\
\hline $24 \cdot 27^{1}$ & 0.18 & 0.7 & 0.37 & $\mathrm{I} \cdot 5$ & 125 & 225 & $12 \cdot 5$ \\
\hline $24 \cdot 04^{I}$ & 0.23 & 0.9 & 0.60 & $2 \cdot 4$ & I 75 & 400 & $3 \cdot 5$ \\
\hline $23 \cdot 82^{I}$ & 0.22 & $0 \cdot 9$ & 0.82 & $3 \cdot 3$ & 275 & 675 & $3 \cdot 8$ \\
\hline $22 \cdot 66^{2}$ & $I \cdot 16$ & $4 \cdot 7$ & I $\cdot 9^{8}$ & $8 \cdot 0$ & $675^{*}$ & $135^{\circ}$ & $6 I \cdot 4$ \\
\hline $22 \cdot \mathrm{II}^{3}$ & 0.55 & $2 \cdot 3$ & $2 \cdot 53$ & 10.3 & $75^{*}$ & 1425 & $4 \cdot 4$ \\
\hline $2 \mathrm{I} \cdot 75^{4}$ & $0 \cdot 3^{6}$ & $I \cdot 4$ & $2 \cdot 89$ & II $\cdot 7$ & $75^{*}$ & 1500 & $7 \cdot 5$ \\
\hline $19 \cdot 36^{5}$ & $2 \cdot 39$ & $9 \cdot 7$ & $5 \cdot 28$ & $2 I \cdot 4$ & $625^{*}$ & 2125 & $32 \cdot 9$ \\
\hline I $8 \cdot 35^{6}$ & $I \cdot O I$ & $4 \cdot 1$ & $6 \cdot 29$ & $25 \cdot 5$ & $375^{*}$ & 2500 & $37 \cdot 5$ \\
\hline
\end{tabular}

${ }^{1}$ Ptarmigan, Lemon Creek and Thomas Glaciers coalesced.

${ }^{2}$ Ptarmigan, 2.62; Lemon Creek and Thomas coalesced, $20 \cdot 04$.

3 Ptarmigan, 2.44; Lemon Creek and Thomas coalesced, 19.67.

${ }_{4}^{4}$ Ptarmigan, 2.35; Lemon Creek and Thomas coalesced, 19.40.

5Ptarmigan, I.96; Lemon Creek, 13.24; and Thomas, 4.16.

${ }^{6}$ Ptarmigan, $1 \cdot 71$; Lemon Creek, 12.67; and Thomas, 3.97.

*Lemon Creek Glacier terminus.

$\mathrm{r} \cdot \mathrm{r} 6 \mathrm{~km} .^{2}$ and an additional $675 \mathrm{~m}$. of retreat. Thereafter, and up until $\mathrm{r} 929$, wastage was again slow, resulting in $0.9 \mathrm{I} \mathrm{km.2}$ of area lost and $150 \mathrm{~m}$. of recession. The second episode of rapid melting has taken place since 1929 . During this time, melting reduced the area by $3.40 \mathrm{~km} .{ }^{2}$ and caused the terminus to recede $\mathrm{I}, 000 \mathrm{~m}$. Since the mid-eighteenth century, the area of the glacier has dwindled 25.5 per cent, more than half of which was lost after 1929 .

The behavior of Lemon Creek Glacier since c. I $75^{\circ}$ when recession began reveals a parallelism with the variations of other glaciers draining along the western side of the Juneau Ice Field. Lawrence (1950[b], I953) finds that the earliest recession began at Herbert Glacier in 1700 while the onset of recession at Mendenhall Glacier was in 1769 and at Eagle Glacier in 1785 . Recession of Gilkey Glacier, which is the neighbor of the Eagle Glacier to the north, was ascertained by the $195^{8}$ field party to have begun about the same time in 1783 . These data illustrate a general condition of recession beginning sometime before 1785 during the eighteenth century.

During the nineteenth century, two noteworthy readvances of Herbert Glacier produced separate sets of multiple moraines. The glacier withdrew from the outer set in 1835 and from the inner one in $\mathrm{r} 86 \mathrm{I}$. At Mendenhall Glacier, recessional moraines are dated c. 1832 and c. 1865 , and tilted trees suggest a readvance sometime between these dates. In accord with this behavior pattern are the slow recession rate for Lemon Creek Glacier between I8I9 and I89 I and the chaotic moraines on the valley floor between these dated positions.

It is significant to compare the amounts of recession since the eighteenth century between Herbert Glacier, as outlined by Lawrence (1950[b]), and those for Lemon Creek Glacier. 


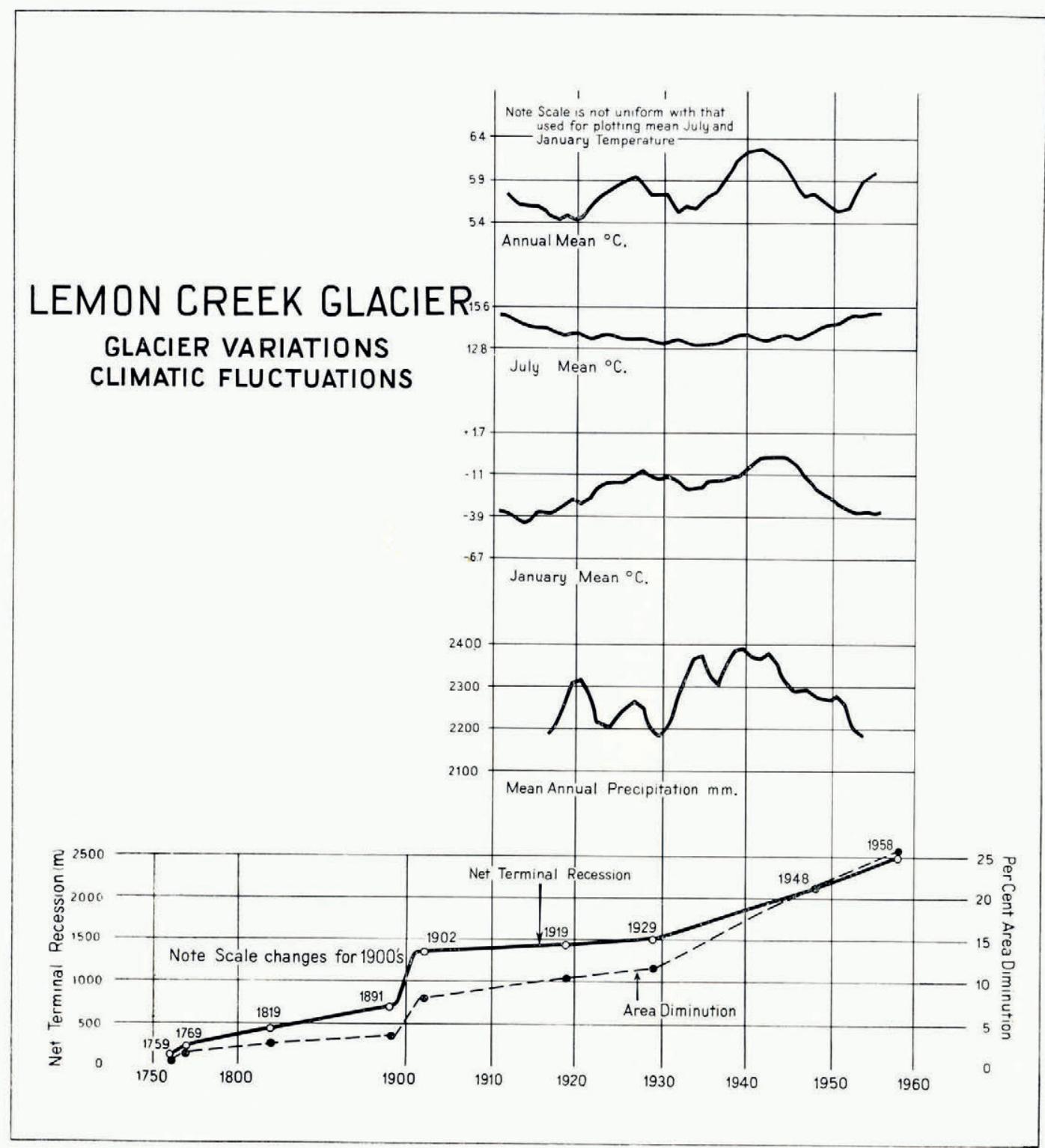

Fig. 2. Net terminal recession and area diminution of Lemon Creek Glacier between the mid-eighteenth century and 1958 compared with Juneau weather records. Temperature and precipitation curves are based on ten-year moving averages

The relatively small amounts at Herbert Glacier during the intervals of $1766-\mathrm{I} 87 \mathrm{I}$ and I910-28 parallel the intervals for Lemon Creek between I769-189i and 1902-29. Rapid recession at the Herbert Glacier during $187 \mathrm{I}-1910$ correlates with the $189 \mathrm{I}-\mathrm{I} 902$ interval at Lemon Creek Glacier. The greatest amount of withdrawal for both glaciers has taken place since I928-29.

In the case of the Taku River valley glaciers, variations correlate generally with those of Lemon Creek Glacier with the exception of the anomalous Taku Glacier which has been 
advancing since early in the twentieth century (Lawrence, 1950[b]; Field, 1954; Heusser and others, I954). It should be pointed out, however, that the beginning of the Taku Glacier advance, as well as the r 916 maximum of the neighboring Norris Glacier, corresponds to the I 902-29 interval when the net amount of recession of Lemon Creek and Herbert Glaciers was small. Farther up the Taku valley, East and West Twin Glaciers receded from a common terminal moraine $c$. 1775 and formed recessional moraines during the nineteenth century between I835 and I877 (Lawrence, I950[b]). Additional correspondence is evident at icedammed Tulsequah Lake, British Columbia, which periodically bursts out by way of Tulsequah River, a tributary of the Taku River. Studies of the history of this lake disclose that the high-water mark did not vary appreciably between $c$. 1910 and 1920, but by 1926 it began to appear lower in elevation (Marcus, I96o). Maintenance of high water in the lake by Tulsequah Glacier suggests little or no change in the glacier, a condition presented by Lemon Creek Glacier for this time span.

\section{Some Notes on Glacier Variations and Climatic Fluctuations}

\section{Following the mid-eighteenth century}

The variations of Lemon Creek Glacier after the maximum dated $c$. $175^{\circ}$ are covered by meteorological observations in Juneau only since the early part of the Igoo's. Continuous measurements of temperature began in 1905 and of precipitation in 1912. Curves of ten-year running averages of the mean July, January and annual temperatures and the mean annual precipitation are plotted and compared with curves of terminal recession and area diminution of the glacier in Figure 2. For the period of glacier variation coinciding with the meteorological record, certain fluctuations of temperature and precipitation can explain the pattern of change shown by the glacier. It should be understood, however, that all variations cannot alone be explained by climatic fluctuations. The topography of the valley, along which the glacier is moving, and the surroundings can often exert considerable influence, intensifying or tempering the effect of climate.

The interval $1902-29$, when the glacier lost only a relatively small quantity of its mass, is best correlated with the mean July temperature curve. Between I9Io and 1930, the net temperature decrease is $2^{\circ} \mathrm{C}$. After 1930 when the glacier began to waste at a rapid rate, the mean July temperature rises a net $2^{\circ} \mathrm{C}$. Although the January mean curve since 19 ro behaves conversely to that for July, no particular significance may be attached to this because winter temperature below freezing will not influence ablation. Summer temperature, as it affects ablation, is of prime importance.

The converse relationship of the July and January temperature curves may be taken as an indication of greater continentality of climate during the early and latest years of meteorological observations. Certainly the mean annual precipitation curve supports this view. Precipitation is greater during the 1930's and early I940's, indicative of maritime conditions, while before and since that period, precipitation is less, reflective of increased continentality.

The glacier receded markedly after $c$. I930 during a time when precipitation was comparatively high. On this basis alone, equilibrium, or even positive regime conditions, should have been created. That such were not created suggests one or more of the following reasons. Precipitation occurred largely as rain at temperatures above freezing; winter accumulation was effectively ablated in summer; and heavy precipitation during the ablation season was a result of the frequent passage of warm storms which, being accompanied by atmospheric turbulence, produced pronounced ablation.

The mean annual temperature curve resembles the curve for mean January temperature; however, the range of the former is only $0.85^{\circ} \mathrm{C}$., whereas the latter ranges over more than $4^{\circ} \mathrm{C}$. The resemblance of the two curves indicates that at least several months have curves closely similar to the one for January. The distinct difference of the July temperature curve 
from the other two discloses the importance of plotting monthly or seasonal curves in addition to the usual plot of annual means.

Maxima of January and annual temperatures are reached in the early 1940's. The July temperature maximum does not coincide with these but is attained during the early I950's. This maximum is probably reached for some other months as well, thereby causing the mean temperature curve to register a rise in the early 1950's. The July curve is shown leveling off in the mid-1950's, but if five-year running averages are drawn, the curve is seen to fall after 1953. These changes during this decade may explain the lower rate of recession for the $194^{8-} 5^{8}$ interval compared with r $929-48$.

The general trend of the mean annual temperature curve, rising between I 9 I 7 and I $94 \mathrm{I}$ (range $0.85^{\circ} \mathrm{C}$.) and falling from $194^{1}$ to $195^{\circ}$ (range $0.74^{\circ} \mathrm{C}$.), finds a parallel in other regions of north-western North America. For example, in western Washington mean annual temperatures register a rise of $0.9^{\circ}$ C. from 1917 to 1943 and a fall of $0.7^{\circ} \mathrm{C}$. from 1943 to I954 (Hubley, I956); along the British Columbia coast, the rise between I 916 and 1943 is $\mathrm{I} \cdot 8^{\circ} \mathrm{C}$. and between 1943 and $\mathrm{I} 95^{2}$ the fall is $\mathrm{I} \cdot 2^{\circ} \mathrm{C}$. (Longley, 1954); in western Alberta, an increase of $\mathrm{I} \cdot 7^{\circ} \mathrm{C}$. occurs during the years $19{ }^{1} 3^{-}-3^{8}$ and a decrease of $\mathrm{I} \cdot 9^{\circ} \mathrm{C}$. from $\mathrm{I} 93^{8}$ to $195^{\circ}$ (Heusser, 1956); and in Montana between 1920 and 1940 temperature increased $\mathrm{I} \cdot 2^{\circ} \mathrm{C}$., while from $194^{\circ}$ to $195^{2}$, it decreased $\mathrm{I} \cdot \mathrm{I}^{\circ} \mathrm{C}$. (Dightman and Beatty, $195^{2}$ ).

Fluctuation of the Juneau mean annual curve during the I920's appears to gain greater prominence at higher latitudes. This is suggested by a comparison of the curves from Washington, British Columbia, Juneau, and the Yukon and Northwest Territories, the last two regions as graphed by Longley (1954). The Juneau and the Yukon and Northwest Territories are remarkably similar, except that the fluctuation of the r 920 's is displaced somewhat into the I93o's.

Variations of the glaciers studied in most of the regions where temperature trends have been graphed also show a general parallel with Lemon Creek Glacier (Heusser, 1957). The advances of the I950's observed in the Rocky, Cascade and Olympic Mountains and elsewhere do not, however, show up in the Juneau area. Decrease in the rate of retreat of Lemon Creek Glacier between $194^{8}$ and $195^{8}$ may represent this trend. According to LaChapelle (I960), the trend shifted for most glaciers in the Pacific north-west between $c$. I954 and I957, yet several continued to advance in 1960 .

Meteorological conditions in the Juneau area before systematic observations began in I 905 may be ascertained qualitatively by inference from glacier behavior and from regional records which started before this date. Only relatively few unbroken records date back to the nineteenth century in north-western North America. Several of those that do have been graphed by Longley (r954) who finds that the r880's were colder than any time since. Warming that immediately followed was interrupted along the British Columbia coast and in the Yukon and the Northwest Territories by another interval of cooling during the first and second decades of the twentieth century. These data substantiate Lemon Creek Glacier variations during this time. Rapid retreat of the terminus between $c$. I $89 \mathrm{I}$ and 1902 corresponds with the rise of temperature after the I880's. The diminished retreat rate before I $89 \mathrm{I}$ and after 1902 is evidently a result of the cooler trend.

Data on precipitation are scanty prior to 1912 when continuous records were begun in Juneau. A precipitation curve for western Washington which dates back to 1887 (Hubley, I956) is in excellent agreement with Juneau fluctuations after 1912, and it is probable that a precipitation peak lasting till $c$. I902, roughly $400 \mathrm{~mm}$. greater than any peak since then, is registered in Juneau as well. The manner in which it affected the glacier regime bringing about rapid recession may have been the same as during the interval after the 1920 's when increased precipitation occurred along with rising temperature. On the other hand, if a lag between climatic fluctuation and glacier variation is considered, the peak precipitation of the late nineteenth century, assuming it took place in Juneau, may have created a condition 
close to equilibrium for Lemon Creek Glacier which was instrumental in reducing the recession rate of $1902-29$. If this has been the case, then the interplay of meteorological conditions has differed at these two times.

Since peak precipitation till c. I902 was under a colder climate than during the I930's peak, it may be assumed that a lower snow line in the early twentieth century resulted in a greater number of positive or equilibrium budget years. The budgets tended to be more and more negative in the 1930's in accordance with a higher snow line. In this regard it is worth quoting the conclusion reached by Hubley (1956) ". . . that the number and intensity of summer storms are the crucial factors in determining the magnitude of glacier ablation in the Juneau Ice Field. On the other hand, storms are also the primary factors in accumulation in the ice field; the location of the atmospheric freezing level relative to the glaciers determines whether a given storm will lead to accumulation or ablation. Of considerable interest is the fact that freezing levels during summer storms on the ice field frequently intersect higher parts of the ice field. A good example is the 1953 storm ... in which $30 \mathrm{~cm}$. of snow on the upper Lemon Creek Glacier was melted in one day. This same storm brought heavy accumulation to the elevated parts of the Juneau Ice Field."

During the eighteenth and early nineteenth century before continuous weather records were maintained, the slow retreat of Lemon Creek Glacier is probably accounted for by a lower snow line or freezing level affected by generally lower summer temperatures. The rise of summer temperature has caused increased ablation of winter accumulation. The advances of the nineteenth century are presumably a response to greater nourishment under conditions of lower temperature. The changes of the oceanic or continental character of the climate have had much to do with these variations.

\section{During millennia since the Ice Age}

Lemon Creek Glacier has not advanced more than $375 \mathrm{~m}$. beyond the maximum of c. 1750 , if at all, during the last $10,000 \mathrm{yr}$. This fact, pointed out previously, indicates that climatic changes have not been vastly more favorable for glaciation at any time since the last ice age. Climatic fluctuations have, however, taken place as shown by regional peat stratigraphy and palynological studies (Heusser, I960). In general, climate improved following the Ice Age, becoming warmer and drier (hypsithermal) between $c$. 8000 and 3500 B.P., and later reverted to coolness and rising humidity. Certain of these fluctuations resulted in glacier growth. The only advances radiocarbon dated thus far in the Juneau area are of nearby Mendenhall Glacier and are between $c$. I 090 and 2790 B.P. (Kulp and others, I95I ; Preston and others, 1955). Because of the proximity of Lemon Creek Glacier, its terminus is suspected of also responding at this time. At Yakutat Bay and Icy Bay, which open on the Gulf of Alaska respectively 370 and $450 \mathrm{~km}$. to the north-west, advances culminated $c .83^{\circ}$ B.P. in the case of the former and I 200 B.P. in the case of the latter (Plafker and Miller, I958).In Glacier Bay, only c. $95 \mathrm{~km}$. north-westerly, numerous age determinations of buried wood point to ice advances not only during the cool and wet episode after $c .3500$ B.P., but also during the warmer and drier hypsithermal millennia at 7000 and 4200 B.P. (Preston and others, 1955; Barendsen and others 1957; Deevey and Flint, 1957). Correlatives of these glacier variations have not as yet been found in the Juneau area. Distinctive moraines of Eagle Glacier, outside the eighteenth century maximum, may show correspondence with the intervals of advance. The climatic change, apparently involving increasing moisture, responsible for each of the advances is, however, suggested by the recurrence surfaces found in muskeg about Juneau and in other parts of south-eastern Alaska. Non-humified peat, accumulated under moist oceanic conditions favorable for glacier nourishment, is overlain by humified peat, developed when a warmer and drier more continental climate, unfavorable for glaciation, prevailed.

That no evidence of a hypsithermal advance of valley glaciers of the Juneau Ice Field has 
been found may be explained by either or both of the following causes: (I) the freezing level or snow line stood at high elevations. Peaks surrounding Glacier Bay reach altitudes of $4,663 \mathrm{~m}$., whereas in the ice field the summit elevation is not higher than 2,616 m. During the times of increased oceanity, even under relatively warm temperatures, the mountains about Glacier Bay accumulated snow and advances resulted; about Juneau, because of a highly elevated freezing level, precipitation was largely in the form of rain. (2) Crustal movement gave rise to glaciation, an opinion expressed by Miller (1958). The Fairweather Range west of Glacier Bay is known to have risen at one place $c .30 \mathrm{~m}$. relative to sea-level in the last $6,000 \mathrm{yr}$., and in another place $c .46 \mathrm{~m}$. in the last 3,00o yr. Isostatic rebound following the Ice Age in the Juneau area was for the most part complete $c .6$, ooo yr. ago. If the rise of land in the neighborhood of Glacier Bay, which is continuing at the present time as indicated by the $195^{8}$ earthquake (Miller, r960), has acted to enlarge the accumulation area in the mountains, the advances of 7,000 and 4,200 B.P. may be in part the result of local crustal activity.

\section{Acknowledgements}

Studies included here were carried out under contract with the U.S. Office of Naval Research (Contract N9 onr-8300 I) with equipment provided by the U.S. Office of the Quartermaster General (Contract DA44-109-qm-1467). At various stages of the project, support was given by the Alaskan Air Command, U.S. Coast Guard, Civil Aeronautics Administration, Snow, Ice and Permafrost Research Establishment, U.S. Corps of Engineers, Air National Guard and U.S. Forest Service.

The authors wish to thank the above organizations and their personnel for contributing time, energy and financial aid which enabled the collection of data interpreted in this paper. They deeply appreciate the interest and assistance of their field companions and particularly wish to thank William O. Field, Edward R. LaChapelle, Charles R. Wilson, Anthony Thomas, Kenneth Løken, Richard B. Scott, Davis V. Bohn, David C. Chappelear and Lawrence E. Nielsen.

MS. received 26 October 1962

\section{REFERENCES}

Barendsen, G. W., and others. 1957. Yale natural radiocarbon measurements III, by G. W. Barendsen, E. S. Deevey and L. J. Gralenski. Science, Vol. r 26, No. 3279, p. 908-r 9.

Deevey, E. S., and Flint, R. F. 1957. Postglacial hypsithermal interval. Science, Vol. 125, No. 3240, p. $182-84$.

Dightman, R. A., and Beatty, M. E. 1952. Recent Montana glacier and climate trends. Monthly Weather Review, Vol. 8o, No. 5, p. 77-81.

Field, W. O. 1954. Notes on the advance of Taku Glacier. Geographical Review, Vol. 44, No. 2, p. $236-39$.

Heusser, C. J. 1956. Postglacial environments in the Canadian Rocky Mountains. Ecological Monographs, Vol. 26, No. 4 , p. $263^{-302 .}$

Heusser, C. J. 1957. Variations of Blue, Hoh, and White Glaciers during recent centuries. Arctic, Vol. ro, No. 3 , p. $139-50$.

Heusser, C. J. 1960. Late-Pleistocene environments of north Pacific North America. American Geographical Society. Special Publication No. 35.

Heusser, C. J., and Marcus, M. G. 1964. Surface movement, hydrological change and equilibrium flow on Lemon Creek Glacier, Alaska. Journal of Glaciology, Vol. 5, No. 37, p. $6 \mathrm{I}-75$.

Heusser, C. J., and others. I954. Geobotanical studies on the Taku Glacier anomaly, by C. J. Heusser, R. L. Schuster and A. K. Gilkey. Geographical Review, Vol. 44, No. 2, p. 224-39.

Hubley, R. C. 1956. Glaciers of the Washington Cascade and Olympic Mountains; their present activity and its relation to local climatic trends. Journal of Glaciology, Vol. 2, No. 19, p. 669-74.

Kulp, J. L., and others. 1951 . Lamont natural radiocarbon measurements I, by J. L. Kuip, H. W. Feely and L. E. Tryon. Science, Vol. I I 4, No. 2970, p. 565-68.

LaChapelle, E. R. 1960. Recent glacier variations in western Washington. Journal of Geophysical Research, Vol. 65 , No. 8, p. 2505. [Abstract.]

Lawrence, D. B. $1950[\mathrm{a}]$. Estimating dates of recent glacier advances and recession rates by studying tree growth layers. Transactions. American Geophysical Union, Vol. 31, No. 2, p. 243-48. 
Lawrence, D. B. 1950[b]. Glacier fluctuation for six centuries in southeastern Alaska and its relation to solar activity. Geographical Review, Vol. 40, No. 2, p. 191-223.

Lawrence, D. B. 1953. Recession of the past two centuries. (First part of Lawrence, D. B., and Elson, J. A. I953. Periodicity of deglaciation in North America since the late Wisconsin maximum. Geografiska Annaler, Arg. 35, Ht. 2, p. 83-104.)

Longley, R. W. 1954. Temperature trends in Canada. Proceedings. Toronto Meteorological Conference, 1953, p. $207-\mathrm{II}$.

Marcus, M. G. I96o. Periodic drainage of glacier-dammed Tulsequah Lake, British Columbia. Geographical Review, Vol. 50, No. I, p. 89-106.

Miller, D. J. I 958 . Anomalous glacial history of the northeastern Gulf of Alaska region. Bulletin of the Geological Society of America, Vol. 69, No. 12, p. 1613-14. [Abstract.]

Miller, D. J. ig6o. Giant waves in Lituya Bay, Alaska. U.S. Geological Survey. Professional Paper 354-C, p. $51-86$. Olson, E. A., and Broecker, W. S. 1959. Lamont natural radiocarbon measurements V. American Journal of Science Radiocarbon Supplement, Vol. 1, p. 1-28.

Plafker, G., and Miller, D. J. 1958. Glacial features and surficial deposits of the Malaspina district, Alaska. U.S. Geological Survey. Miscellaneous Geological Investigations, Map I-27I.

Preston, R. S., and others. I955. Yale natural radiocarbon measurements II, by R. S. Preston, E. Person and E. S. Deevey. Science, Vol. 122, No. 3177, p. 954-60. 